Pediat. Res. 10: 176-178 (1976)

Cystic fibrosis

fucose

$\mathrm{L}-\left[{ }^{3} \mathrm{H}\right] \mathrm{fucose}$ serum factor skin fibroblasts

\title{
Absence of a Serum Factor in Patients with Cystic Fibrosis
}

\author{
LIANG CHOU AND HENRY NADLER ${ }^{(21)}$ \\ Department of Pediatrics, Northwestern University Medical School, Division of Genetics, \\ The Children's Memorial Hospital, Chicago, Illinois, USA
}

\begin{abstract}
Extract
A serum factor was demonstrated in normal individuals which (1) enhances the incorporation of $\mathrm{L}-\left[{ }^{3} \mathrm{H}\right]$ fucose into cultured human skin fibroblasts, (2) is nondialyzable, (3) is heat labile at $50^{\circ},(4)$ is present in the noneuglobulin fraction, and (5) appears to be deficient in serum from patients with cystic fibrosis. The specific activity of $\mathrm{L}-\left[{ }^{3} \mathbf{H}\right]$ fucose incorporated into skin fibroblasts from normal individuals in the presence of serum from 12 control subjects was 3,337 $\pm 168 \mathrm{cpm} / \mathrm{mg}$ protein in contrast to $2,294 \pm 172$, the activity obtained either in the presence of serum from 10 age-matched patients with cystic fibrosis or in the absence of serum. These differences were significant at $P<0.001$. In comparison, no significant difference was detected in the amount of $\mathrm{L}-\left[{ }^{3} \mathrm{H}\right]$ fucose incorporated into skin fibroblasts derived from normal individuals and patients with cystic fibrosis. The plasma membrane of cultured skin fibroblasts derived from patients with cystic fibrosis appears to be grossly unaltered in its protein and L-fucose labeling pattern.
\end{abstract}

\section{Speculation}

The plasma membrane of cultured skin fibroblasts derived from patients with cystic fibrosis is not altered. The abnormalities at the plasma membrane level as previously reported may be the consequence of the interaction between the factor described here and plasma membranes.

Cystic fibrosis is an autosomal recessive disorder in which the basic defect is unknown (8). Abnormalities in cellular transport mechanisms at the plasma membrane level have been proposed to explain elevated ion concentrations in various secretions of patients with cystic fibrosis. Studies from several laboratories have shown that saliva, sweat, and plasma from patients with cystic fibrosis can alter the movement of various molecules across plasma membrane $(6,11,13)$. In addition, a serum factor from patients with cystic fibrosis has been reported to cause disorganization of the ciliary beat of explants of rabbit trachea (16) and cessation of the ciliary beat of oysters (5) and mussels (3). Since the ciliary movement has been suggested to be controlled by the cell membrane (15), the anticiliary effect of serum factor found in patients with cystic fibrosis could be the consequence of the interaction between the factor and plasma membranes. Fitzpatrick et al. (10) have shown that membranes of red blood cells obtained from patients with cystic fibrosis frequently demonstrate an alteration in electrophoretic patterns on polyacrylamide gels. A similar alteration of electrophoretic patterns occurred when membranes isolated from normal red blood cells were incubated with $\mathrm{CaCl}_{2}$. These observations strongly suggest the involvement of plasma membranes in cystic fibrosis. The possible alteration in plasma membranes could represent either a primary defect or a secondary manifestation resulting from the interaction between the "factors" and plasma membranes.

In order to evaluate the potential abnormalities of plasma membranes in patients with cystic fibrosis, L- $\left[{ }^{3} \mathrm{H}\right]$ fucose incorporation into cultured skin fibroblasts from normal individuals and patients with cystic fibrosis was studied. This approach was utilized as previous studies have shown that much of the L-fucose taken up by several types of mammalian cells was directly incorporated into the plasma membrane fraction $(1,4)$. Similar protein patterns and $\mathrm{L}$-fucose labeling patterns were obtained with plasma membranes prepared from cultured skin fibroblasts from normal individuals and patients with cystic fibrosis. A serum factor was demonstrated in normal individuals which enhances the incorporation of $\mathrm{L}-\left[{ }^{3} \mathrm{H}\right]$ fucose into cultured skin fibroblasts and appears to be deficient in serum from patients with cystic fibrosis. In contrast, there is no significant difference in the amount of $\mathrm{L}-\left[{ }^{3} \mathrm{H}\right]$ fucose incorporated into skin fibroblasts derived from normal individuals and patients with cystic fibrosis.

\section{MATERIALS AND METHODS}

\section{CELL CULTURES AND SERA}

Skin fibroblasts derived from normal individuals and patients with cystic fibrosis were grown in minimal essential medium supplemented with $15 \%$ fetal calf serum, penicillin, streptomycin, and fungizone as described previously (14). Serum samples obtained from 10 children with cystic fibrosis, 2 obligate heterozygotes, and 12 age-matched control subjects were dialyzed against

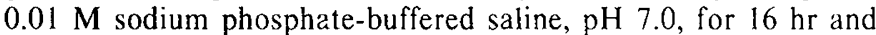
stored at $-20^{\circ}$. Skin biopsies and serum samples were obtained with informed consent under the guidelines of the Department of Health, Education and Welfare and with the approval of the Human Ethics and Research Committee of The Children's Memorial Hospital.

\section{LABELING, PREPARATION, AND ELECTROPHORESIS OF PLASMA MEMBRANES}

The culture medium was replaced with fresh medium containing $0.5 \mu \mathrm{Ci} / \mathrm{ml} \mathrm{L}-\left[{ }^{3} \mathrm{H}\right]$ fucose (specific activity: $3.18 \mathrm{Ci} / \mathrm{mmol}$ ) $(18)$ on the third day after subculture. After incubation for $16 \mathrm{hr}$, the cells were harvested by scraping with a rubber policeman. The plasma membrane fraction was prepared by using sucrose and Ficoll gradients according to the method of Warren et al. (17) and examined under a phase-contrast microscope. The purified membrane fraction was then solubilized and separated by electrophoresis on a sodium dodecyl sulfate-polyacrylamide gel as described by Fairbanks et al. (9) except that $0.5 \mathrm{M}$ urea was added. After electrophoresis, the gel was sliced and incubated at $50^{\circ}$ for $2 \mathrm{hr}$ with $0.5 \mathrm{ml}$ NCS solubilizer $\mathrm{H}_{2} \mathrm{O}(9: 1)$ (18). The radioactivity was determined in a liquid scintillation counter (19) with ${ }^{3} \mathrm{H}$ efficiency of $45 \%$. The gels were stained for protein with Coomassie blue.

\section{ASSAY OF L- $\left[{ }^{3} \mathrm{H}\right]$ FUCOSE INCOR PORATION}

At confluency, fibroblasts were removed from flasks by scraping with a rubber policeman. After washing twice with $0.15 \mathrm{M} \mathrm{NaCl}$, 
cells were suspended in $0.01 \mathrm{M}$ sodium phosphate-buffered saline, $\mathrm{pH} 7.0$, and $0.5 \%(\mathrm{w} / \mathrm{v})$ bovine serum albumin. The reaction mixture $(0.15 \mathrm{ml})$ contained $0.01 \mathrm{M}$ sodium phosphate-buffered saline, $\mathrm{pH} 7.0,0.5 \%(\mathrm{w} / \mathrm{v})$ bovine serum albumin, fibroblasts (1 $\mathrm{mg}$ total protein as determined by the method of Lowry et al. (12), $0.05-0.15 \mathrm{ml}$ dialyzed serum and $5 \mu \mathrm{Ci} \mathrm{L-}\left[{ }^{3} \mathrm{H}\right]$ fucose (specific activity: $4.3 \mathrm{Ci} / \mathrm{mmol}$ ) (18). After íncubation at $37^{\circ}$, cells were washed twice with cold $0.01 \mathrm{M}$ sodium phosphate-buffered saline, $\mathrm{pH} 7.0$, and precipitated with $5 \%$ trichloroacetic acid. The precipitate was then dissolved in $2 \mathrm{~N} \mathrm{NaOH}$ and the radioactivity was determined as described above.

\section{RESULTS}

Figure 1 shows the protein pattern and L- $\left[{ }^{3} \mathrm{H}\right]$ fucose labeling pattern of purified plasma membranes prepared from cultured skin fibroblasts derived from normal individuals. A similar pattern was obtained with the plasma membrane prepared from patients with cystic fibrosis. These observations are similar to those recently reported by Baig et al. (2).

Figure 2 shows the time course of $\mathrm{L}-\left[{ }^{3} \mathrm{H}\right]$ fucose incorporation into trichloroacetic acid-precipitable material of human skin fibroblasts. There is no difference in the time course of $\mathrm{L}$ $\left[{ }^{3} \mathrm{H}\right]$ fucose incorporation into skin fibroblasts from normal individuals in the absence of serum or in the presence of serum from patients with cystic fibrosis. In contrast, a significant increase in $\mathrm{L}-\left[{ }^{3} \mathrm{H}\right]$ fucose incorporation was observed with the addition of serum from normal control subjects. This stimulatory effect of $\mathrm{L}-\left[{ }^{3} \mathrm{H}\right]$ fucose incorporation into fibroblasts with serum from control subjects is clearly shown in Figure 3. A linear increase in the amount of $\mathrm{L}-\left[{ }^{3} \mathrm{H}\right]$ fucose incorporation into fibroblasts was obtained with increasing amounts of serum obtained from 12 control subjects. Serum samples from 10 age-matched children with cystic fibrosis failed to show any stimulation.

As shown in Table 1, the specific activity of $\mathrm{L}-\left[{ }^{3} \mathrm{H}\right]$ fucose incorporated into skin fibroblasts from normal individuals in the presence of serum from 12 control subjects was determined to be $3,337 \pm 168$ (mean $\pm \mathrm{SD}$ ) which is significantly higher than the value of $2,294 \pm 172$ obtained in the presence of serum from 10 age-matched patients with cystic fibrosis $(P<0.001)$. The average value of $\mathrm{L}-\left[{ }^{3} \mathrm{H}\right]$ fucose incorporation with serum from two obligate heterozygotes was similar to that from control subjects. Mixing serum from control subjects and patients with cystic fibrosis yielded an intermediate value of 2,803 . This observation appears to exclude the possibility that an inhibitor is present in serum from patients with cystic fibrosis or an activator is present in serum

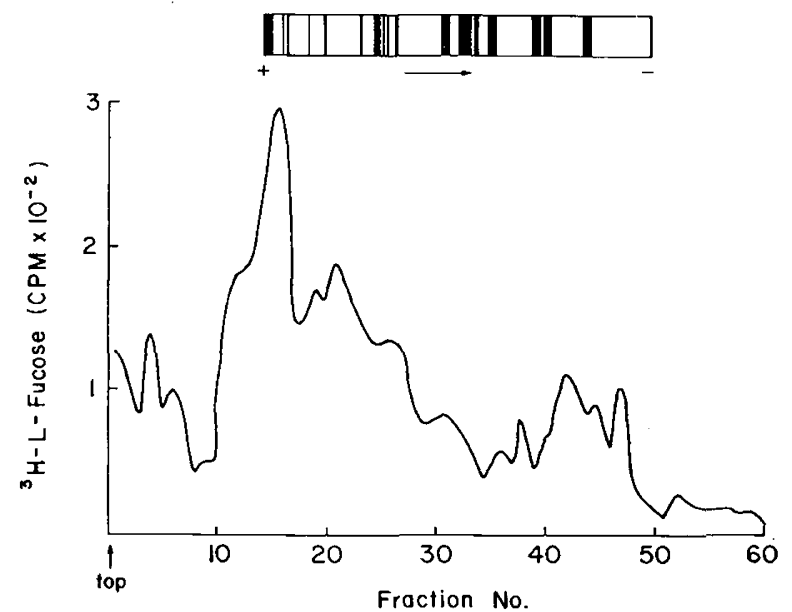

Fig. 1. The protein pattern and $\mathrm{L}-\left[{ }^{3} \mathrm{H}\right]$ fucose labeling pattern of purified plasma membranes. The plasma membrane fraction was prepared as described under Materials and Methods from cultured skin fibroblasts derived from normal individuals. Top: protein pattern; bottom: $\mathrm{L}-\left[{ }^{3} \mathrm{H}\right]-$ fucose labeling pattern.

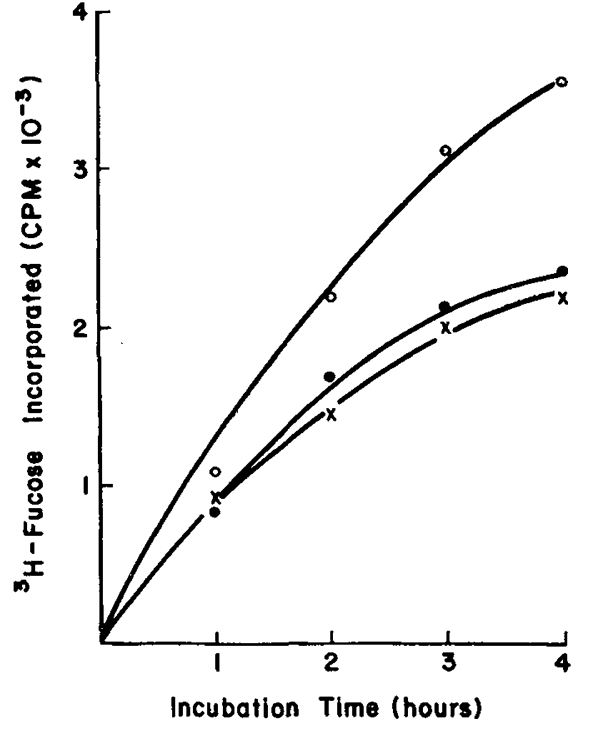

Fig. 2. Time course of $\mathrm{L}-\left[{ }^{3} \mathrm{H}\right]$ fucose incorporation. The amount of $\mathrm{L}-\left[{ }^{3} \mathrm{H}\right]$ fucose incorporated was determined in the absence of serum $(-)$ ), in the presence of $0.15 \mathrm{ml}$ of serum from controls $(\mathrm{O}-\mathrm{O})$ and from patients with cystic fibrosis $(\times-\times)$. The points represent the average of experiments with serum samples from three normal individuals and three patients with cystic fibrosis.

from control subjects. Results as shown Table $I$ also revealed no significant difference in the amount of $\mathrm{L}-\left[{ }^{3} \mathrm{H}\right]$ fucose incorporated into skin fibroblasts derived from five normal individuals and two patients with cystic fibrosis. The factor was found to be present in the noneuglobulin fraction of control serum which did not precipitate after dialysis against water saturated with $\mathrm{CO}_{2}$ at $4^{\circ}$, was inactivated with heating at $50^{\circ}$ for $30 \mathrm{~min}$, and was in the $0-30 \%(w / v)$ ammonium sulfate fraction of normal serum.

\section{DISCUSSION}

These data demonstrate the presence of a serum factor in normal individuals which $(l)$ enhances the incorporation of L- $\left[{ }^{3} \mathrm{H}\right]$ fucose into cultured human skin fibroblasts, (2) is nondialyzable, (3) is heat labile at $50^{\circ},(4)$ is present in the noneuglobulin fraction, and (5) is absent in serum from patients with cystic fibrosis. This factor is distinguishable from the factor described by Spock et al. (16) which was found to be associated with the euglobulin fraction of serum and present in the patients with cystic fibrosis and obligate heterozygotes.

As has been shown in Figure 2, there was a significant amount of $\mathrm{L}-\left[{ }^{3} \mathrm{H}\right] \mathrm{fucose}$ incorporated into skin fibroblasts in the absence of serum. This endogenous incorporation could be due to the presence of fetal calf serum in the culture medium for skin fibroblasts since substantial enhancement of $\mathrm{L}-\left[{ }^{3} \mathrm{H}\right]$ fucose incorporation was also observed with fetal calf serum (7). The intermediate value obtained by mixing equal amounts of serum from control subjects and patients with cystic fibrosis (Table 1) strongly suggests the absence of an inhibitor in serum from patients with cystic fibrosis and an activator in serum from normal individuals. The absence of an inhibitor in serum from patients with cystic fibrosis was also shown in Figure 3. There was no significant inhibition of $\mathrm{L}-\left[{ }^{3} \mathrm{H}\right]$ fucose incorporation with increasing concentration of serum from patients with cystic fibrosis to a final concentration of $30 \%$. Since the nature of the stimulator of the L-fucose incorporation is, at present, not clear, definite conclusions can only be drawn when the factor is isolated and characterized. The values of $\mathrm{L}-\left[{ }^{3} \mathrm{H}\right]$ fucose incorporation with serum from obligate heterozygotes were found to be within the range of control values. This assay is, at present, unable to determine heterozygotes of cystic fibrosis. Future experiments can be directed towards increasing the sensitivity of the assay by minimizing the amount of $\mathrm{L}$-fucose incorporation in the absence of serum and purifying the factor. 


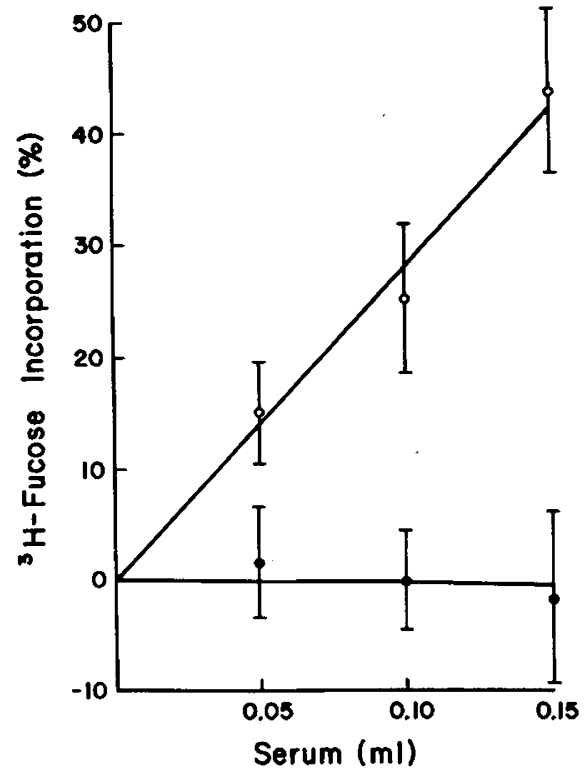

Fig. 3. Effect of serum concentration on $\mathrm{L}-\left[{ }^{3} \mathrm{H}\right]$ fucose incorporation. The reaction was incubated at $37^{\circ}$ for $3 \mathrm{~h}$. Values were calculated from: [(incorporation with serum - incorporation without serum)/(incorporation without serum)] $\times 100 \%$ with serum samples from 12 control subjects $(\mathrm{O}-\mathrm{O})$ and 10 patients with cystic fibrosis $(-\infty)$ and expressed as mean $\pm \mathrm{SD}$.

Table 1. $L-\left[{ }^{3} \mathrm{H}\right]$ Fucose incorporation into human skin fibroblasts ${ }^{1}$

\begin{tabular}{llll}
\hline Serum & Fibroblasts & \multicolumn{1}{c}{$\begin{array}{c}\text { L- }\left[{ }^{3} \mathrm{H}\right] \text { Fucose incorporated, } \\
\text { cpm } / \text { mg protein }\end{array}$} \\
\hline $\mathrm{N}$ & $\mathrm{N}$ & $3,337 \pm 168(12)$ & \\
$\mathrm{CF}$ & $\mathrm{N}$ & $2,294 \pm 172(10)$ & $P<0.001$ \\
$\mathrm{CF}$ Het & $\mathrm{N}$ & $3,224(2)$ & \\
Mixed & $\mathrm{N}$ & $2,803(2)$ & \\
$\mathrm{N}$ & $\mathrm{CF}$ & $3,430(2)$ & \\
$\mathrm{CF}$ & $\mathrm{CF}$ & $2,344(2)$ & \\
$\mathrm{N}^{2}$ & $\mathrm{~N}$ & $3,650 \pm 204(7)$ & \\
$\mathrm{CF}$ & $\mathrm{N}$ & $2,240 \pm 174(9)$ & \\
$\mathrm{N}^{3}$ & $\mathrm{~N}$ & $2,370(2)$ & \\
$\mathrm{CF}^{3}$ & $\mathrm{~N}$ & $2,354(2)$ & \\
$\mathrm{N}^{4}$ & $\mathrm{~N}$ & $2,434 \pm 134(4)$ & \\
\hline
\end{tabular}

${ }^{1} \mathrm{~N}$ : normal control subjects; CF: cystic fibrosis, CF Het: obligatory heterozygotes. Values are expressed as mean $\pm \mathrm{SD}$. The number of samples is shown in parentheses. $P$ values were determined by using the Student $t$ test.

${ }^{2}$ Noneuglobulin fractions.

${ }^{3}$ Euglobulin fractions.

${ }^{4}$ Inactivated at $50^{\circ}$ for $30 \mathrm{~min}$.

The plasma membrane of skin fibroblasts derived from patients with cystic fibrosis may not be altered since the protein pattern and the L-fucose labeling pattern of purified plasma membrane of fibroblasts from patients with cystic fibrosis were found to be similar to those from control subjects. Similar observations were reported recently by Baig et al. (2) with plasma membranes prepared by a different method. In addition, the amount of $\mathrm{L}$-fucose incorporated into skin fibroblasts derived from control subjects and patients with cystic fibrosis was also shown to be similar.

Since the factor described here was shown to participate in the metabolism of L-fucose containing glycoproteins in plasma mem- branes, it is reasonable to assume that the factor may be important for the plasma membrane to carry out certain physiologic functions. The abnormalities in cellular transport mechanisms at the plasma membrane level, as reported previously in patients with cystic fibrosis, may be the consequence of the interaction between the factor described here and plasma membranes.

\section{SUMMARY}

A serum factor was demonstrated in normal individuals which (1) enhances the incorporation of $\mathrm{L}-\left[{ }^{3} \mathrm{H}\right]$ fucose into cultured human skin fibroblasts, (2) is nondialyzable, (3) is heat labile at $50^{\circ},(4)$ is present in the noneuglobulin fraction, and (5) is absent in serum from patients with cystic fibrosis. In contrast, there is no significant difference in the amount of L- $\left[{ }^{3} \mathrm{H}\right]$ fucose incorporated into skin fibroblasts derived from normal individuals and patients with cystic fibrosis. The plasma membrane of cultured skin fibroblasts derived from patients with cystic fibrosis is grossly unaltered in its protein and L-fucose labeling patterns. The abnormalities at the plasma membrane level, as previously reported, may be the consequence of the interaction between the factor described here and plasma membranes.

\section{REFERENCES AND NOTES}

1. Atkinson, P. H., and Summers, D. F.: Purification and properties of HeLa cell plasma membranes. J. Biol. Chem., 210: 5162 ('971).

2. Baig, M. M., Cetorelli, J. J., and Roberts, R. M.: Plasma membrane components of skin fibroblasts from normal individuals and patients with cystic fibrosis. J. Pediat., 86: 72 (1975).

3. Besley, G. N. T., Patrick, A. D., and Norman, A. P.: Inhibition of the motility of gill cilia of Dreissensia by plasma of cystic fibrosis patients and their parents. J. Med. Genet., 6: 278 (1969).

4. Bosmann, H. B., Hagopian, A., and Eglar, E. H.: Cellular membranes: the biosynthesis of glycoprotein and glycolipid in HeLa cell membranes. Arch. Biochem. Biophys., 130: 573 (1969).

5. Bowman, G. H., Lockhart, L. H., and McCombs, M. L.: Oyster ciliary inhibition by cystic fibrosis factor. Science, 164: 325 (1969).

6. Brown, G. A., Oshin, A., Goodchild, M. C., and Anderson, C. M: Inhibition of sugar transport by plasma from cystic fibrosis patients. Lancet, ii: 639 (1971).

7. Chou, L., and Nadler, H. L.: Unpublished data.

8. di Sant' Agnese, P. A., and Talamo, R. C.: Pathogenesis and physiopathology of cystic fibrosis of the pancreas. Fibrocystic disease of the pancreas (mucoviscidosis). N. Engl. J. Med. 277: 1287, 1343, 1399 (1967).

9. Fairbanks, G., Steck, T. L., and Wallach, D. F. H.: Electrophoretic analysis of the major polypeptides of the human erythrocyte membrane. Biochemistry, 10: 2606 (1971).

10. Fitzpatrick, D. F., Landon, E. J., and James, V.: Serum binding of calcium and the red cell membrane in cystic fibrosis. Nature New Biol., 235: 173 (1972).

11. Kaiser, D., Drack, E., and Rossi, E.: Inhibition of net sodium transport in single sweat glands by sweat of patients with cystic fibrosis of the pancreas. Pediat. Res., 5: 167 (1971).

12. Lowry, O. M., Rosebrough, N. J., Farr, A. L., and Randall, R. J.: Protein measurement with Folin phenol reagent. J. Biol. Chem., 193: 265 (1951).

13. Mangos, J. A., McSherry, N. R., and Benke, P. J.: A sodium transport inhibitory factor in the saliva of patients with cystic fibrosis of the pancreas. Pediat. Res., 1: 436 (1967).

14. Nadler, H. L., Inouye, T., Justice, P., and Hsia, D. Y-Y.: Enzymes in cultivated human fibroblasts derived from patients with Down's syndrome (mongolism). Nature, 213: 1261 (1967).

15. Naitoh, Y., and Eckert, R.: Ciliary orientation: Controlled by cell membrane or by intracellular fibrils? Science, 166: 1633 (1969).

16. Spock, A., Heick, H. M. C., Cress, H., and Logan, W. S.: Abnormal serum factor in patients with cystic fibrosis of the pancreas. Pediat. Res., I: 173 (1967).

17. Warren, L., Glick, M. C., and Nass, M. K.: In: B. D. Davis and L. Warren: The Specificity of Cell Surfaces, p. 109 (Prentice-Hall, Englewood Cliff, N. J., 1967).

18. New England Nuclear, Boston, Mass.

19. Mark II liquid scintillation counter, Nuclear Chicago, Chicago, Ill.

20. We thank Drs. L. E. Gibson and J. Perman for obtaining blood samples from patients with cystic fibrosis.

21. H. L. Nadler is the Irene Heinz Given and John La Porte Given Research Professor of Pediatrics.

22. These studies were supported by grants from The National Heart and Lung Institute HL 17130 and The National Foundation-March of Dimes.

23. Requests for reprints should be addressed to: H. L. Nadler, M.D., Children's Memorial Hospital, 2300 Children's Plaza, Chicago, I11. 60614 (USA).

24. Accepted for publication October 31, 1975. 